\title{
Group III metabotropic glutamate receptors and drug addiction
}

\author{
Limin Mao, Minglei Guo, Daozhong Jin, Bing Xue, and John Q. Wang ${ }^{\bowtie}$ \\ Department of Basic Medical Science, School of Medicine, University of Missouri-Kansas City, \\ Kansas City, MO 64108, USA
}

\begin{abstract}
Neuroadaptations of glutamatergic transmission in the limbic reward circuitry are linked to persistent drug addiction. Accumulating data have demonstrated roles of ionotropic glutamate receptors and group I and II metabotropic glutamate receptors (mGluRs) in this event. Emerging evidence also identifies Gai/o-coupled group III mGluRs (mGluR4/7/8 subtypes enriched in the limbic system) as direct substrates of drugs of abuse and active regulators of drug action. Autoand heteroreceptors of mGluR4/7/8 reside predominantly on nerve terminals of glutamatergic corticostriatal and GABAergic striatopallidal pathways, respectively. These presynaptic receptors regulate basal and/or phasic release of respective transmitters to maintain basal ganglia homeostasis. In response to operant administration of common addictive drugs, such as psychostimulants (cocaine and amphetamine), alcohol and opiates, limbic group III mGluRs undergo drastic adaptations to contribute to the enduring remodeling of excitatory synapses and to usually suppress drug seeking behavior. As a result, a loss-of-function mutation (knockout) of individual group III receptor subtypes often promotes drug seeking. This review summarizes the data from recent studies on three group III receptor subtypes (mGluR4/7/8) expressed in the basal ganglia and analyzes their roles in the regulation of dopamine and glutamate signaling in the striatum and their participation in the addictive properties of three major classes of drugs (psychostimulants, alcohol, and opiates).
\end{abstract}

\section{Keywords}

group III metabotropic glutamate receptors; cocaine; amphetamine; alcohol; opiate

\section{Introduction}

L-glutamate (glutamate) is a major neurotransmitter in the mammalian brain. This transmitter interacts with both ionotropic glutamate receptors (iGluRs) and metabotropic glutamate receptors (mGluRs) to mediate or regulate a variety of cellular activities and synaptic transmission [1]. The mGluRs belong to the G protein-coupled receptor family. Through various $G$ proteins, they connect to multiple intracellular second messenger systems. Based on the connection specificity, eight mGluR subtypes (mGluR1-8) so far cloned are classified into three functional groups [2]. Group I mGluRs (mGluR1 and 5 subtypes) are coupled to Gaq proteins, through which mGluR1/5 signals activate phospholipase $\mathrm{C} \beta 1$. This activation increases phosphoinositol hydrolysis, resulting in

\footnotetext{
(C) Higher Education Press and Springer-Verlag Berlin Heidelberg 2013

Correspondence: wangjq@umkc.edu.

Compliance with ethics guidelines

Limin Mao, Minglei Guo, Daozhong Jin, Bing Xue, and John Q. Wang declare that they have no conflict of interest. This manuscript is a review article and does not involve a research protocol requiring approval by the relevant institutional review board or ethics committee.
} 
intracellular $\mathrm{Ca}^{2+}$ release and protein kinase $\mathrm{C}$ (PKC) activation [2]. Both group II (mGluR2/3) and group III (mGluR4/6/7/8) receptors are coupled to Gai/o proteins. Activation of them inhibits adenylyl cyclase and cAMP formation, thereby limiting downstream protein kinase A (PKA) activation. Since mGluRs function through their downstream signaling pathways, they usually modulate relatively slow cellular responses as opposed to iGluRs that usually mediate fast synaptic transmission in the central nervous system.

Drug addiction is a persistent cognitive disorder that is characterized by compulsive drug craving, seeking, and ingestion in spite of severe adverse consequences [3,4]. The potential brain mechanisms underlying this disorder remain elusive. Available data support a notion that long-lasting neuroadaptations in the limbic reward circuitry induced by repeated exposure of drugs of abuse mediate addictive behavior [4,5]. The ventral tegmental area (VTA) is a key component of the reward circuitry. The VTA dopaminergic neurons project to the ventral striatum/nucleus accumbens (NAc) and the prefrontal cortex (PFC). The latter together with other limbic structures such as the hippocampus and amygdala send glutamatergic projections to the NAc. These limbic areas are the main central substrates of drugs and are actively involved in drug action [4]. In addition, the dorsal striatum/caudate putamen $(\mathrm{CPu})$ receives dopaminergic and glutamatergic inputs from the substantia nigra (SN) and the cortex, respectively, and contributes to learning and memory and compulsive disorders [5].

Enriched glutamatergic innervation and dense pre- and postsynaptic glutamate receptor distribution in basal ganglia reward structures situate glutamate well as an equally important regulator as dopamine in drug addiction. As supported by accumulated data [6,7], basal ganglia glutamatergic components are sensitive to addictive drugs, such as psychostimulants (cocaine and amphetamine), alcohol, and opiates. In response to repeated exposure of drugs, glutamatergic transmission undergoes enduring remodeling and adaptations, leading to addictive behavior. Indeed, iGluRs have been extensively investigated, and their adaptations and contributions to drug action have been reviewed previously [8-10]. Group I and II mGluRs are also important for drug addiction, as reviewed elsewhere [11-15]. In addition to group I/II mGluRs, group III mGluRs are expressed in the mesolimbic reward system. While investigation of group III mGluRs seems to be still trailing behind group I/II receptors, available data support their emerging roles in drug action. In this review, we will summarize progress from the studies concerning group III mGluRs. We will mainly review three group III mGluR subtypes (4/7/8) as they are enriched in the reward circuitry related to drug addiction, while another group III subtype (mGluR6) is expressed only in the retina (see below). Of note, the importance of group III mGluRs is not limited to addiction. Malfunctional group III mGluRs have been linked to the pathogenesis of many other neurological diseases, such as schizophrenia [16], anxiety [16,17], and Parkinson's disease $[17,18]$.

\section{Localization and function of group III mGluRs in the reward circuitry}

Like other brain regions, localization of group III mGluRs in the basal ganglia is predominantly presynaptic [19] (Fig. 1). Both mGluR4 and 7 presynaptic autoreceptors are seen on the glutamatergic corticostriatal terminals $[18,19]$. They are also found on nerve terminals of GABAergic striatopallidal and striatonigral pathways and serve as presynaptic heteroreceptors [20-22]. mGluR8 mRNAs are expressed in the cortex and striatum [23]. A possibility is thus that these receptors could presynaptically reside on corticostriatal and/or striatonigral/striatopallidal terminals. mGluR6 is restrictedly expressed in the retina, but not in the basal ganglia [24]. As such, mGluR6 is reasoned to play an insignificant role in drug addiction. Compared to the dominant presynaptic distribution, the postsynaptic distribution 
of group III mGluRs in the basal ganglia is less clear [18] and is limited to some postsynaptic mGluR7 in striatal neurons [21]. Thus, focus at present remains on the presynaptic site when localization and function of group III mGluRs are investigated.

Electrophysiological experiments with available pharmacological agents selective at either the group or the subtype level have provided evidence for potential functional roles of these receptors in different reward pathways. In the corticostriatal pathway, group III receptor agonists, L-serine-O-phosphate (L-SOP) and L-2-amino-4-phosphonobutyrate (L-AP4), suppressed synaptic responses to cortical stimulation in postsynaptic striatal neurons [2527]. This may result from the inhibition of glutamate release from corticostriatal terminals, likely through presynaptic mGluR4 [27]. The mGluR8 agonist (S)-3,4-

dicarboxyphenylglycine [ $(S)$-DCPG] did not produce the same effect as the above agonists [27]. Thus, the mGluR8's function in regulating corticostriatal synapses, if mGluR8 is present on presynaptic terminals, remains elusive. Group III receptors also inhibit the GABAergic striatopallidal pathway. L-AP4 depressed striatal-evoked synaptic responses, inhibitory postsynaptic currents (IPSCs), in the globus pallidus $[28,29]$. This effect may be due to the inhibition of GABA release from striatopallidal terminals [30], and mGluR4 activation seems to be crucial [29,31]. At GABAergic striatonigral synapses, L-AP4 inhibited striatal-evoked IPSCs in the substantia nigra [32]. Thus, at either glutamatergic or GABAergic synaptic sites surveyed so far in the basal ganglia reward circuitry, group III mGluRs (one or more subtypes) consistently act to inhibit synaptic transmission via a presynaptic mechanism.

\section{Psychostimulants}

An early study noted the impact of group III receptor agents on behavioral responses to acute cocaine [33]. In chronically cannulated and conscious rats, microinjection of the group III receptor agonist L-AP4 or antagonist MPPG into the $\mathrm{CPu}$ did not alter basal motor activity [33], although L-AP4 injected into the NAc induced relatively modest motor stimulation [34]. Of note, L-AP4 injected into the CPu reduced hyperlocomotion induced by acute cocaine or amphetamine, and MPPG reversed this effect [33]. Similarly, L-AP4 activation of MPPG-sensitive group III receptors in the rat NAc attenuated locomotor responses to amphetamine [35]. Systemic administration of a new group III agonist, (1S,3R, 4S)-1-aminocyclo-pentane-1,3,4-tricarboxylic acid (ACPT-I), reduced the behavioral effect of amphetamine [36]. Thus, group III mGluRs in both the dorsal and ventral striatum regulate behavioral responsivity to psychostimulants. And an enhanced receptor activity usually functions to lower behavioral sensitivity to stimulants. How group III receptors and which subtype of them regulate motor sensitivity to stimulants is unclear. The presynaptic regulation of local transmitter release by these receptors may cast light. L-AP4 has been found to reduce extracellular dopamine levels in the CPu and NAc, whereas MPPG enhanced dopamine in these regions [37,38]. More importantly, L-AP4 attenuated amphetamine-stimulated dopamine release in the $\mathrm{CPu}$ [38]. Thus, by inhibiting dopamine release, group III receptors may inhibit motor responses to stimulants. The receptor can directly inhibit dopamine release through the group III heteroreceptor on dopaminergic terminals if their presence on the terminal can be proven. Alternatively, the receptor can indirectly regulate dopamine release via glutamate. Striatal glutamate has long been recognized to facilitate dopamine release [39]. Inhibition of glutamate release by group III autoreceptors may result in parallel depression of dopamine release. At present, whether group III receptors directly modulate the phasic glutamate release in the striatum induced by stimulants remains to be an interesting topic, while L-AP4 and the group III receptor antagonist (R, S)-a-methylserine-O-phosphate (MSOP) decreased and increased the baseline extracellular level of glutamate in the rat NAc, respectively [40]. In addition to the regulation of transmitter release by an auto- or heteroreceptor mechanism, mGluR7a shows 
the presence at postsynaptic sites in both striatonigral and striatopallidal medium spiny output neurons [21]. L-AP4 in fact showed inhibition of evoked synaptic responses in the NAc at least partially via a postsynaptic mechanism [41]. Thus, postsynaptic inhibition of striatal cellular responses to stimulants is possible. This postsynaptic mechanism, if there is, is likely to cooperate with the presynaptic modulation to dynamically control synaptic and motor responses to drugs.

Neuroadaptations of group III mGluRs may occur in response to chronic stimulant exposure and may accordingly regulate the long-term effect of drugs. Like other glutamate receptors, group III mGluRs are sensitive targets of stimulants. While acute cocaine reduced mGluR8 protein expression in the rat striatum [42], chronic amphetamine induced a profound increase in mGluR8 mRNAs in the rat striatum and especially cerebral cortex [43]. A longlasting nature of this increase, as it remained 21 days after drug withdrawal, is noticeable. It is appreciated that altered gene expression, if lasted long enough, could be a critical transcription-dependent adaptation contributing to the enduring receptor plasticity and drug addiction. Thus, the increased mGluR8 mRNA expression, if it can be translated to a parallel increase in protein expression and function, may reflect an important element in the remodeling of excitatory synapses related to behavioral plasticity. In addition, a robust increase in cortical mGluR8 may lead to an increased number of mGluR8 autoreceptors on corticostriatal terminals. This enhances mGluR8 tone on glutamate release from this pathway and allows mGluR8 to participate in the reshaping of excitatory synapses. In the central amygdala, loss of group III mGluR function was revealed in rats after chronic cocaine exposure [44].

Operant drug self-administration paradigm provides a robust animal model for mimicking core features of addiction in humans. Increasing evidence from studies using this model shows the reliable participation of iGluRs and group I/II mGluRs in drug seeking behavior [8-15]. Recently, investigators have started to pay attention to group III mGluRs and have utilized this model to define the role of these receptors in drug consumption. Systemic administration of the mGluR7 selective allosteric agonist N, $\mathrm{N}^{\prime}$-dibenzyhydryl-ethane-1,2diamine dihydrochloride (AMN082) inhibited cocaine self-administration [45]. AMN082 had no impact on sucrose self-administration, indicating the specific inhibition of cocaine reward by this agent. Microinjection of AMN082 into the NAc, although not the $\mathrm{CPu}$, was effective as systemic administration [45]. An mGluR7 selective allosteric antagonist 6-(4methoxyphenyl)-5-methyl-3-pyridin-4-ylisoxazolo [4,5-c]pyridine-4(5H)-one (MMPIP) blocked the AMN082 effect. Similar to the self-administration model, AMN082 inhibited cocaine-induced enhancement of electrical brain-stimulation reward [45] and reinstatement of cocaine-seeking in a rat relapse model [46]. These data support the role of mGluR7 in cocaine seeking. Of note, AMN082, unlike L-AP4, selectively alters extracellular levels of GABA and glutamate, but not dopamine [47]. This suggests that AMN082 may target a pathway downstream to NAc dopamine (i.e., the NAc-ventral pallidum GABAergic pathway) to exert its anti-cocaine effect. In support of this, local injection of AMN082 into the ventral pallidum inhibited cocaine self-administration [47].

\section{Alcohol}

As for other drugs of abuse, alcohol induces changes in the limbic reward system. These experience-dependent neuroadaptations contribute at least in part to alcohol dependence (alcoholism). Among adaptations at multiple levels, plastic changes in glutamatergic transmission play a central role [48]. Regarding group III mGluRs, several recent studies unravel their importance in glutamate receptor plasticity and alcohol seeking. Current attention seems to focus on mGluR7, probably due to (1) its relatively higher concentration in the basal ganglia compared to other group III subtypes, (2) its highest evolutionary 
conservation among all mGluRs suggesting significant physiological roles [49], and (3) its genetic linkage to heritable ethanol drinking [50]. In the first study linking mGluR7 to alcohol seeking behavior, Vadasz et al. identified mGluR7 as a cis-regulated gene for alcohol consumption, and mice carrying mutations that lead to lower mGluR7 transcript expression consumed more alcohol than controls [50]. In a recent study, the mGluR7 allosteric agonist AMN082 reduced rat ethanol consumption and preference without affecting taste preference [51], although the other study in mice found that AMN082 reduced both ethanol and sucrose administration [52]. AMN082 also reduced the reinstatement of ethanol-induced conditioned place preference [53]. In contrast to AMN082, the mGluR7 selective antagonist MMPIP enhanced ethanol intake and reversed the effect of AMN082 [51,53]. In mGluR7 knockout mice, alcohol consumption was increased relative to wild-type mice [54]. Viral-mediated mGluR7 knockdown in the NAc induced excessive alcohol drinking and augmented ethanol-induced conditioned place preference [55]. Apparently, mGluR7 possesses the ability to suppress alcohol drinking as seen in the case of cocaine. Loss of mGluR7 activity contributes to plastic changes in glutamatergic transmission, leading to drug seeking behavior.

Other group III receptor subtypes have also been studied for their implications in alcohol effects. Mice lacking mGluR4 showed a higher motor response to novelty than did wild-type mice [56]. However, these mutant mice did not show the stimulatory motor activity in response to a behaviorally active dose of ethanol. There were no differences between mutant and wild-type strains in ethanol consumption or preference, severity of ethanol-induced acute withdrawal, or duration of loss of righting reflex. Thus, mGluR4 is involved in mediating ethanol-induced motor stimulation, although the receptor seems to lack the association with ethanol consumption. The mGluR8 selective agonist $(S)-3,4-$ dicarboxyphenylglycine [(S)-3,4-DCPG], when administered systemically, attenuated rat alcohol self-administration (reinforcing effect of alcohol) and cue-induced reinstatement of alcohol seeking [57]. This suggests the inhibitory modulation of the addictive properties of alcohol by mGluR8. However, (S)-3,4-DCPG also decreased spontaneous locomotor activity [57]. Therefore, an mGluR8 agent with less motor-suppressant side effects is preferred to clarify the distinct modulation of mGluR8 on alcohol seeking behavior.

\section{Opiates}

While glutamate is important for opiate dependence, only a few reports have described potential anti-addictive activity of group III mGluRs toward opiates so far.

Intracerebroventricular injections of the group III receptor antagonist a-methyl-L-amino-4phosphonobutanoate (MAP4) decreased the time spent in morphine withdrawal in rats [58]. However, MAP4 is known to activate group II mGluRs [58]. Thus, a further investigation using a group III receptor selective agonist ACPT-I was carried out in mice to define the specific role of group III mGluRs [59]. Peripheral administration of this agonist attenuated all morphine withdrawal symptoms, including vertical jumping, wet dog shake, paw shake, body tremor, and body weight loss [59]. Mechanisms underlying the effect of ACPT-I are unclear. The presynaptic regulation of transmitter release may again play a role. An increase in glutamate release has been seen during morphine withdrawal $[60,61]$, which is believed to link to withdrawal symptoms. Thus, ACPT-I may stimulate presynaptic group III receptors to inhibit glutamate release, thereby attenuating the symptoms. In addition, the probability of GABA release in the VTA was increased during withdrawal from chronic morphine due to the upregulated cAMP-dependent signaling [62]. This could be one adaptive mechanism underlying morphine withdrawal symptoms. ACPT-I may therefore activate group III mGluR heteroreceptors to inhibit GABA release and attenuate withdrawal symptoms. 


\section{Conclusions}

Glutamatergic transmission in the basal ganglia has now been appreciated to be critical for drug addiction. Early studies have established iGluRs and mGluRs (mainly group I/II) as direct substrates of drugs and active regulators of drug effects. In response to drug exposure, these receptors in striatal and cortical neurons show marked and dynamic changes in expression, trafficking/redistribution, and function. For group III mGluRs, even though limited studies have been attempted at present, emerging evidence ties them to the remodeling of excitatory synapses and persistent drug seeking. The high level of expression of mGluR7 in the limbic reward circuitry implies its roles in drug action. In fact, evidence associates this receptor with addictive effects of psychostimulants, alcohol, and opiates. In addition to mGluR7, mGluR4 and mGluR8 are important for drug action. Due to a predominant presynaptic distribution pattern, group III mGluRs are believed to exert their roles via a presynaptic mechanism, although a postsynaptic modulation to a certain extent cannot be ruled out. It is anticipated that studies on group III receptor in the addiction research field will grow rapidly. The advancement of developing (1) pharmacological agents with higher subtype selectivity and (2) conditional knockout mouse lines will facilitate these studies. All future research efforts will ultimately inform group III mGluRs as to their clinical relevance, and assist in our understanding the pathogenesis of psychiatric illnesses and in developing therapeutic agents for drug addiction.

\section{Acknowledgments}

The work by the authors discussed in this article was supported by NIH R01 DA010355 and R01 MH061469.

\section{References}

1. Dingledine R, Borges K, Bowie D, Traynelis SF. The glutamate receptor ion channels. Pharmacol Rev. 1999; 51(1):7-61. [PubMed: 10049997]

2. Conn PJ, Pin JP. Pharmacology and functions of metabotropic glutamate receptors. Annu Rev Pharmacol Toxicol. 1997; 37(1):205-237. [PubMed: 9131252]

3. Koob GF, Le Moal M. Drug addiction, dysregulation of reward, and allostasis. Neuropsychopharmacology. 2001; 24(2):97-129. [PubMed: 11120394]

4. Kalivas PW, Volkow ND. The neural basis of addiction: a pathology of motivation and choice. Am J Psychiatry. 2005; 162(8):1403-1413. [PubMed: 16055761]

5. Graybiel AM. Habits, rituals, and the evaluative brain. Annu Rev Neurosci. 2008; 31(1):359-387. [PubMed: 18558860]

6. Tzschentke TM, Schmidt WJ. Glutamatergic mechanisms in addiction. Mol Psychiatry. 2003; 8(4): 373-382. [PubMed: 12740594]

7. Hyman SE, Malenka RC, Nestler EJ. Neural mechanisms of addiction: the role of reward-related learning and memory. Annu Rev Neurosci. 2006; 29(1):565-598. [PubMed: 16776597]

8. Kalivas PW. The glutamate homeostasis hypothesis of addiction. Nat Rev Neurosci. 2009; 10(8): 561-572. [PubMed: 19571793]

9. Bowers MS, Chen BT, Bonci A. AMPA receptor synaptic plasticity induced by psychostimulants: the past, present, and therapeutic future. Neuron. 2010; 67(1):11-24. [PubMed: 20624588]

10. Schmidt HD, Pierce RC. Cocaine-induced neuroadaptations in glutamate transmission: potential therapeutic targets for craving and addiction. Ann N Y Acad Sci. 2010; 1187(1):35-75. [PubMed: 20201846]

11. Kenny PJ, Markou A. The ups and downs of addiction: role of metabotropic glutamate receptors. Trends Pharmacol Sci. 2004; 25 (5):265-272. [PubMed: 15120493]

12. Bird MK, Lawrence AJ. Group I metabotropic glutamate receptors: involvement in drug-seeking and drug-induced plasticity. Curr Mol Pharmacol. 2009; 2(1):83-94. [PubMed: 20021449] 
13. Moussawi K, Kalivas PW. Group II metabotropic glutamate receptors (mGlu2/3) in drug addiction. Eur J Pharmacol. 2010; 639 (1-3):115-122. [PubMed: 20371233]

14. Olive MF. Cognitive effects of Group I metabotropic glutamate receptor ligands in the context of drug addiction. Eur J Pharmacol. 2010; 639(1-3):47-58. [PubMed: 20371237]

15. Ribeiro FM, Paquet M, Cregan SP, Ferguson SS. Group I metabotropic glutamate receptor signalling and its implication in neurological disease. CNS Neurol Disord Drug Targets. 2010; 9(5):574-595. [PubMed: 20632969]

16. Wierońska JM, Pilc A. Metabotropic glutamate receptors in the tripartite synapse as a target for new psychotropic drugs. Neurochem Int. 2009; 55(1-3):85-97. [PubMed: 19428811]

17. Lavreysen H, Dautzenberg FM. Therapeutic potential of group III metabotropic glutamate receptors. Curr Med Chem. 2008; 15(7):671-684. [PubMed: 18336281]

18. Duty S. Therapeutic potential of targeting group III metabotropic glutamate receptors in the treatment of Parkinson's disease. Br J Pharmacol. 2010; 161(2):271-287. [PubMed: 20735415]

19. Conn PJ, Battaglia G, Marino MJ, Nicoletti F. Metabotropic glutamate receptors in the basal ganglia motor circuit. Nat Rev Neurosci. 2005; 6(10):787-798. [PubMed: 16276355]

20. Bradley SR, Standaert DG, Levey AI, Conn PJ. Distribution of group III mGluRs in rat basal ganglia with subtype-specific antibodies. Ann N Y Acad Sci. 1999; 868:531-534. [PubMed: 10414330]

21. Kosinski CM, Risso Bradley S, Conn PJ, Levey AI, Land-wehrmeyer GB, Penney JB Jr, Young $\mathrm{AB}$, Standaert DG. Localization of metabotropic glutamate receptor $7 \mathrm{mRNA}$ and mGluR7a protein in the rat basal ganglia. J Comp Neurol. 1999; 415 (2):266-284. [PubMed: 10545164]

22. Corti C, Aldegheri L, Somogyi P, Ferraguti F. Distribution and synaptic localisation of the metabotropic glutamate receptor 4 (mGluR4) in the rodent CNS. Neuroscience. 2002; 110(3):403420. [PubMed: 11906782]

23. Messenger MJ, Dawson LG, Duty S. Changes in metabotropic glutamate receptor $1-8$ gene expression in the rodent basal ganglia motor loop following lesion of the nigrostriatal tract. Neuropharmacology. 2002; 43(2):261-271. [PubMed: 12213280]

24. Nakajima Y, Iwakabe H, Akazawa C, Nawa H, Shigemoto R, Mizuno N, Nakanishi S. Molecular characterization of a novel retinal metabotropic glutamate receptor mGluR6 with a high agonist selectivity for L-2-amino-4-phosphonobutyrate. J Biol Chem. 1993; 268(16):11868-11873. [PubMed: 8389366]

25. Pisani A, Calabresi P, Centonze D, Bernardi G. Activation of group III metabotropic glutamate receptors depresses glutamatergic transmission at corticostriatal synapse. Neuropharmacology. 1997; 36(6):845-851. [PubMed: 9225312]

26. Manzoni O, Michel JM, Bockaert J. Metabotropic glutamate receptors in the rat nucleus accumbens. Eur J Neurosci. 1997; 9 (7):1514-1523. [PubMed: 9240409]

27. Cuomo D, Martella G, Barabino E, Platania P, Vita D, Madeo G, Selvam C, Goudet C, Oueslati N, Pin JP, Acher F, Pisani A, Beurrier C, Melon C, Kerkerian-Le Goff L, Gubellini P. Metabotropic glutamate receptor subtype 4 selectively modulates both glutamate and GABA transmission in the striatum: implications for Parkinson's disease treatment. J Neurochem. 2009; 109(4):1096-1105. [PubMed: 19519781]

28. Marino MJ, Williams DL Jr, O’Brien JA, Valenti O, McDonald TP, Clements MK, Wang R, DiLella AG, Hess JF, Kinney GG, Conn PJ. Allosteric modulation of group III metabotropic glutamate receptor 4: a potential approach to Parkinson's disease treatment. Proc Natl Acad Sci USA. 2003; 100(23):13668-13673. [PubMed: 14593202]

29. Valenti O, Marino MJ, Wittmann M, Lis E, DiLella AG, Kinney GG, Conn PJ. Group III metabotropic glutamate receptor-mediated modulation of the striatopallidal synapse. J Neurosci. 2003; 23(18):7218-7226. [PubMed: 12904482]

30. Macinnes N, Duty S. Group III metabotropic glutamate receptors act as hetero-receptors modulating evoked GABA release in the globus pallidus in vivo. Eur J Pharmacol. 2008; 580(1-2): 95-99. [PubMed: 18035348]

31. Beurrier C, Lopez S, Révy D, Selvam C, Goudet C, Lhérondel M, Gubellini P, Kerkerian-LeGoff L, Acher F, Pin JP, Amalric M. Electrophysiological and behavioral evidence that modulation of 
metabotropic glutamate receptor 4 with a new agonist reverses experimental parkinsonism. FASEB J. 2009; 23(10):3619-3628. [PubMed: 19525404]

32. Wittmann M, Marino MJ, Conn PJ. Dopamine modulates the function of group II and group III metabotropic glutamate receptors in the substantia nigra pars reticulata. J Pharmacol Exp Ther. 2002; 302(2):433-441. [PubMed: 12130700]

33. Mao L, Wang JQ. Distinct inhibition of acute cocaine-stimulated motor activity following microinjection of a group III metabotropic glutamate receptor agonist into the dorsal striatum of rats. Pharmacol Biochem Behav. 2000; 67(1):93-101. [PubMed: 11113488]

34. Swanson CJ, Kalivas PW. Regulation of locomotor activity by metabotropic glutamate receptors in the nucleus accumbens and ventral tegmental area. J Pharmacol Exp Ther. 2000; 292(1):406-414. [PubMed: 10604977]

35. David HN, Abraini JH. Blockade of the locomotor stimulant effects of amphetamine by group I, group II, and group III metabotropic glutamate receptor ligands in the rat nucleus accumbens: possible interactions with dopamine receptors. Neuropharmacology. 2003; 44 (6):717-727. [PubMed: 12681370]

36. Pałucha-Poniewiera A, Kłodzińska A, Stachowicz K, Tokarski K, Hess G, Schann S, Frauli M, Neuville P, Pilc A. Peripheral administration of group III mGlu receptor agonist ACPT-I exerts potential antipsychotic effects in rodents. Neuropharmacology. 2008; 55(4):517-524. [PubMed: 18619473]

37. Hu G, Duffy P, Swanson C, Ghasemzadeh MB, Kalivas PW. The regulation of dopamine transmission by metabotropic glutamate receptors. J Pharmacol Exp Ther. 1999; 289(1):412-416. [PubMed: 10087032]

38. Mao L, Lau YS, Wang JQ. Activation of group III metabotropic glutamate receptors inhibits basal and amphetamine-stimulated dopamine release in rat dorsal striatum: an in vivo microdialysis study. Eur J Pharmacol. 2000; 404(3):289-297. [PubMed: 10996594]

39. Wang JQ, McGinty JF. Glutamate-dopamine interactions mediate the effects of psychostimulant drugs. Addict Biol. 1999; 4(2):141-150. [PubMed: 20575780]

40. Xi ZX, Shen H, Baker DA, Kalivas PW. Inhibition of non-vesicular glutamate release by group III metabotropic glutamate receptors in the nucleus accumbens. J Neurochem. 2003; 87(5):12041212. [PubMed: 14622100]

41. Martin G, Nie Z, Siggins GR. Metabotropic glutamate receptors regulate $N$-methyl-D-aspartatemediated synaptic transmission in nucleus accumbens. J Neurophysiol. 1997; 78(6):3028-3038. [PubMed: 9405522]

42. Zhang GC, Vu K, Parelkar NK, Mao LM, Stanford IM, Fibuch EE, Wang JQ. Acute administration of cocaine reduces metabotropic glutamate receptor 8 protein expression in the rat striatum in vivo. Neurosci Lett. 2009; 449(3):224-227. [PubMed: 19010389]

43. Parelkar NK, Wang JQ. Upregulation of metabotropic glutamate receptor 8 mRNA expression in the rat forebrain after repeated amphetamine administration. Neurosci Lett. 2008; 433(3):250-254. [PubMed: 18255232]

44. Neugebauer V, Zinebi F, Russell R, Gallagher JP, Shinnick-Gallagher P. Cocaine and kindling alter the sensitivity of group II and III metabotropic glutamate receptors in the central amygdala. J Neurophysiol. 2000; 84(2):759-770. [PubMed: 10938303]

45. Li X, Li J, Peng XQ, Spiller K, Gardner EL, Xi ZX. Metabotropic glutamate receptor 7 modulates the rewarding effects of cocaine in rats: involvement of a ventral pallidal GABAergic mechanism. Neuropsychopharmacology. 2009; 34(7):1783-1796. [PubMed: 19158667]

46. Li X, Li J, Gardner EL, Xi ZX. Activation of mGluR7s inhibits cocaine-induced reinstatement of drug-seeking behavior by a nucleus accumbens glutamate-mGluR2/3 mechanism in rats. J Neurochem. 2010; 114(5):1368-1380. [PubMed: 20534005]

47. Li X, Gardner EL, Xi ZX. The metabotropic glutamate receptor 7 ( $\left.\mathrm{mGluR}_{7}\right)$ allosteric agonist AMN082 modulates nucleus accumbens GABA and glutamate, but not dopamine, in rats. Neuropharmacology. 2008; 54(3):542-551. [PubMed: 18155073]

48. Spanagel R, Kiefer F. Drugs for relapse prevention of alcoholism: ten years of progress. Trends Pharmacol Sci. 2008; 29(3):109-115. [PubMed: 18262663] 
49. Flor PJ, Van Der Putten H, Rüegg D, Lukic S, Leonhardt T, Bence M, Sansig G, Knöpfel T, Kuhn R. A novel splice variant of a metabotropic glutamate receptor, human mGluR7b. Neuropharmacology. 1997; 36(2):153-159. [PubMed: 9144652]

50. Vadasz C, Saito M, Gyetvai BM, Oros M, Szakall I, Kovacs KM, Prasad VV, Toth R. Glutamate receptor metabotropic 7 is cis-regulated in the mouse brain and modulates alcohol drinking. Genomics. 2007; 90(6):690-702. [PubMed: 17936574]

51. Bahi A, Fizia K, Dietz M, Gasparini F, Flor PJ. Pharmacological modulation of mGluR7 with AMN082 and MMPIP exerts specific influences on alcohol consumption and preference in rats. Addict Biol. 2012; 17(2):235-247. [PubMed: 21392179]

52. Salling MC, Faccidomo S, Hodge CW. Nonselective suppression of operant ethanol and sucrose self-administration by the mGluR7 positive allosteric modulator AMN082. Pharmacol Biochem Behav. 2008; 91(1):14-20. [PubMed: 18593591]

53. Bahi A. The selective metabotropic glutamate receptor 7 allosteric agonist AMN082 prevents reinstatement of extinguished ethanol-induced conditioned place preference in mice. Pharmacol Biochem Behav. 2012; 101(2):193-200. [PubMed: 22269296]

54. Gyetvai B, Simonyi A, Oros M, Saito M, Smiley J, Vadász C. mGluR7 genetics and alcohol: intersection yields clues for addiction. Neurochem Res. 2011; 36(6):1087-1100. [PubMed: 21448595]

55. Bahi A. Viral-mediated knockdown of mGluR7 in the nucleus accumbens mediates excessive alcohol drinking and increased ethanol-elicited conditioned place preference in rats. Neuropsychopharmacology. 2013; 38(11):2109-2119. [PubMed: 22781839]

56. Blednov YA, Walker D, Osterndorf-Kahanek E, Harris RA. Mice lacking metabotropic glutamate receptor 4 do not show the motor stimulatory effect of ethanol. Alcohol. 2004; 34(2-3):251-259. [PubMed: 15902920]

57. Bäckström P, Hyytiä P. Suppression of alcohol self-administration and cue-induced reinstatement of alcohol seeking by the mGlu2/3 receptor agonist LY379268 and the mGlu8 receptor agonist (S)-3,4-DCPG. Eur J Pharmacol. 2005; 528(1-3):110-118. [PubMed: 16324694]

58. Fundytus ME, Ritchie J, Coderre TJ. Attenuation of morphine withdrawal symptoms by subtypeselective metabotropic glutamate receptor antagonists. Br J Pharmacol. 1997; 120(6):1015-1020. [PubMed: 9134211]

59. Pałucha-Poniewiera A, Novák K, Pilc A. Group III mGlu receptor agonist, ACPT-I, attenuates morphine-withdrawal symptoms after peripheral administration in mice. Prog Neuropsychopharmacol Biol Psychiatry. 2009; 33(8):1454-1457. [PubMed: 19660510]

60. Tokuyama S, Wakabayashi H, Ho IK. Direct evidence for a role of glutamate in the expression of the opioid withdrawal syndrome. Eur J Pharmacol. 1996; 295(2-3):123-129. [PubMed: 8720575]

61. Guo M, Xu NJ, Li YT, Yang JY, Wu CF, Pei G. Morphine modulates glutamate release in the hippocampal CA1 area in mice. Neurosci Lett. 2005; 381(1-2):12-15. [PubMed: 15882781]

62. Bonci A, Williams JT. Increased probability of GABA release during withdrawal from morphine. J Neurosci. 1997; 17(2):796-803. [PubMed: 8987801] 

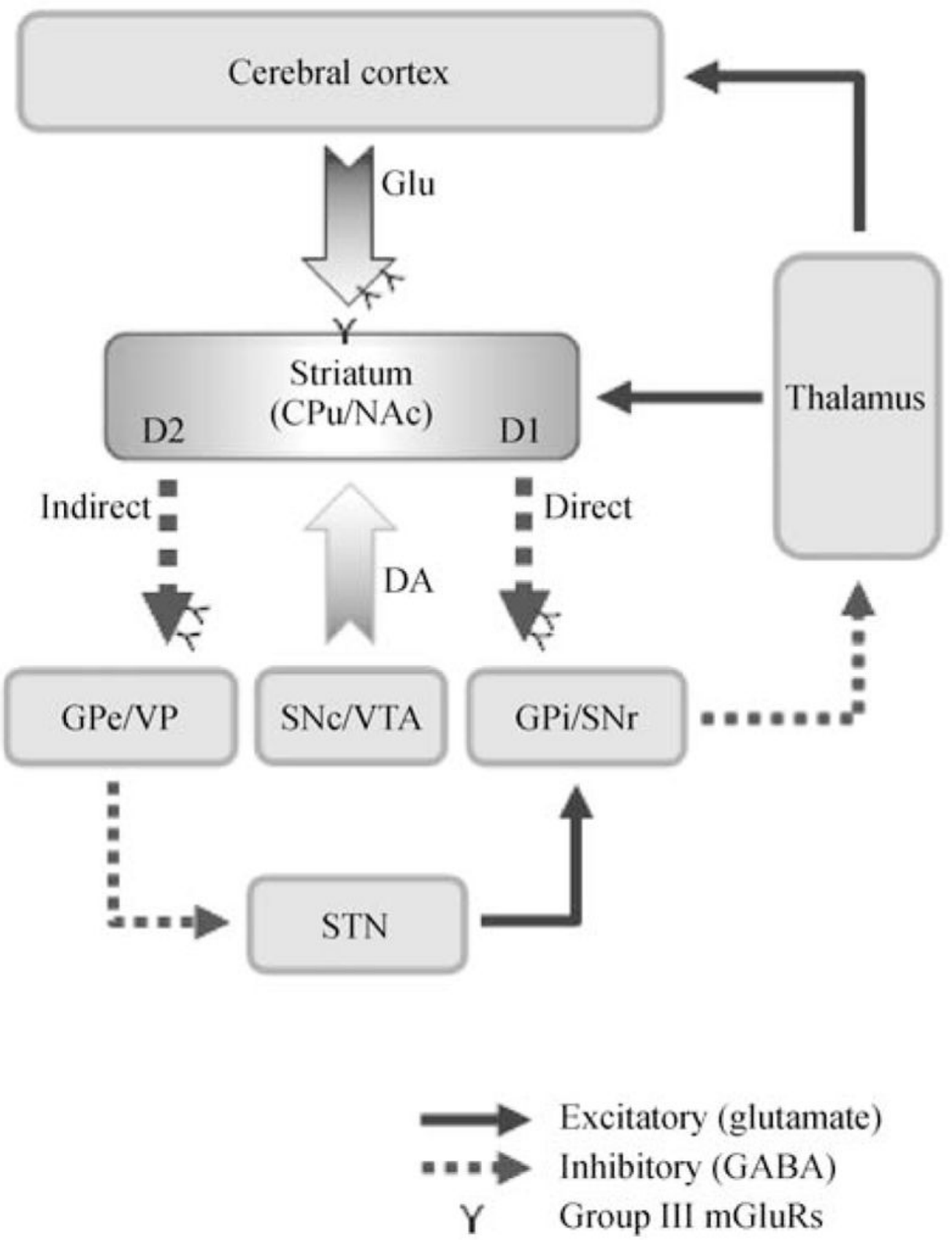

Fig. 1.

A schematic diagram illustrating distribution of group III mGluRs in the basal ganglia. The striatum $(\mathrm{CPu}$ and $\mathrm{NAc})$ receives dopaminergic inputs from the substantia nigra pars compacta (SNc) and VTA and glutamatergic (Glu) inputs from the cerebral cortex, thalamus, and other forebrain areas (i.e., glutamatergic inputs from the hippocampus and amygdala to the NAc). Striatal neurons project two GABAergic pathways (D1 receptormediated direct and D2 receptor-mediated indirect pathways) to regulate outflow of the basal ganglia to the motor cortex. Group III mGluRs (mGluR4, mGluR7, and/or mGluR8) are distributed primarily in presynaptic terminals. Other abbreviations: GPe, external globus 
pallidus; GPi, internal globus pallidus; $\mathrm{VP}$, ventral pallidum; $\mathrm{SNr}$, substantia nigra pars reticulata; STN, subthalamic nucleus. 